University of Wollongong

Research Online

Sydney Business School - Papers

Faculty of Business and Law

2012

\title{
A new approach for considering a dual-role factor in data envelopment analysis
}

Abdollah Noorizadeh

Lappeenranta University of Technology

Mahdi Mahdiloo

University of Wollongong, mahdim@uow.edu.au

Reza Farzipoor Saen

Islamic Azad University

Follow this and additional works at: https://ro.uow.edu.au/gsbpapers

Part of the Business Commons

\section{Recommended Citation}

Noorizadeh, Abdollah; Mahdiloo, Mahdi; and Saen, Reza Farzipoor: A new approach for considering a dualrole factor in data envelopment analysis 2012, 135-155.

https://ro.uow.edu.au/gsbpapers/552

Research Online is the open access institutional repository for the University of Wollongong. For further information contact the UOW Library: research-pubs@uow.edu.au 


\title{
A new approach for considering a dual-role factor in data envelopment analysis
}

\begin{abstract}
The conventional data envelopment analysis models deal with dualrole factor as non-discretionary (uncontrollable) factor. However, there might be dual-role factor which is under control of decision-maker. In addition, despite the fact that there are several publications addressing dual-role factors, it seems that their idea of classifying a factor as an input or an output within a single model has a limitation. They also do not consider non-zero input and output slacks and cannot fully measure the inefficiency of decisionmaking units. To resolve these limitations and to consider dual-role factor as well, this paper proposes a slacks-based measure model which does not consider dualrole factor as a non-discretionary factor. To compare the results of proposed approach with conventional model, a statistical analysis is run. A numerical example demonstrates the application of the proposed method. Copyright 2012 Inderscience Enterprises Ltd.
\end{abstract}

\section{Keywords}

envelopment, data, approach, factor, analysis, dual-role, considering

Disciplines

Business

\section{Publication Details}

Noorizadeh, A., Mahdiloo, M. \& Saen, R. Farzipoor. (2012). A new approach for considering a dual-role factor in data envelopment analysis. International Journal of Operational Research, 14 (2), 135-155. 


\title{
A new approach for considering a dual-role factor in data envelopment analysis
}

\author{
Abdollah Noorizadeh, Mahdi Mahdiloo \\ and Reza Farzipoor Saen*
}

Faculty of Management and Accounting, Department of Industrial Management, Islamic Azad University - Karaj Branch, P.O. Box 31485-313, Karaj, Iran

Fax: +98 2614418156

E-mail: ab.noorizadeh@gmail.com

E-mail: ma.mahdiloo@gmail.com

E-mail: farzipour@yahoo.com

*Corresponding author

\begin{abstract}
The conventional data envelopment analysis models deal with dualrole factor as non-discretionary (uncontrollable) factor. However, there might be dual-role factor which is under control of decision-maker. In addition, despite the fact that there are several publications addressing dual-role factors, it seems that their idea of classifying a factor as an input or an output within a single model has a limitation. They also do not consider non-zero input and output slacks and cannot fully measure the inefficiency of decision-making units. To resolve these limitations and to consider dual-role factor as well, this paper proposes a slacks-based measure model which does not consider dualrole factor as a non-discretionary factor. To compare the results of proposed approach with conventional model, a statistical analysis is run. A numerical example demonstrates the application of the proposed method.
\end{abstract}

Keywords: DEA; data envelopment analysis; dual-role factor; SBM; slacksbased measure; contingency table.

Reference to this paper should be made as follows: Noorizadeh, A., Mahdiloo, M. and Saen, R.F. (2012) 'A new approach for considering a dualrole factor in data envelopment analysis', Int. J. Operational Research, Vol. 14, No. 2, pp. 135-155.

Biographical notes: Abdollah Noorizadeh is a Consultant in the Area of Management. Currently, he obtained his BSc in Industrial Management from the Islamic Azad University - Karaj Branch in Iran. He has published papers in journals, such as Journal of Industrial and Management Optimization, Int. J. Academic Research and Int. J. Productivity and Quality Management.

Mahdi Mahdiloo is a Consultant in the Area of Management. Currently, he obtained his BSc in Industrial Management from the Islamic Azad University Karaj Branch in Iran. He has published papers in journals, such as Journal of Industrial and Management Optimization, Int. J. Academic Research and Int. J. Productivity and Quality Management.

Reza Farzipoor Saen is an Associate Professor in the Department of Industrial Management at Islamic Azad University-Karaj Branch, Iran. He completed his $\mathrm{PhD}$ in Industrial Management from Islamic Azad University-Science and 
Research Branch, Iran, in 2002. He has published over 64 refereed papers in many prestigious journals, such as Journal of the Operational Research Society, Applied Mathematics and Computation, European Journal of Operational Research, Annals of Operations Research, World Applied Sciences Journal, Int. J. Advanced Manufacturing Technology, Int. J. Applied Management and Technology, Asia Pacific Management Review, Int. J. Information Systems and Supply Chain Management, etc.

\section{Introduction}

Data envelopment analysis (DEA) has been widely applied to address various decision analysis problems due to its usefulness in evaluating multi-criterion systems. DEA is a non-parametric mathematical programming technique that determines an efficient frontier of the most efficient decision-making units (DMUs) and calculates the efficiency of each DMU relative to this efficient frontier based on multiple observed inputs and outputs. An efficiency score of a DMU is generally defined as the weighted sum of outputs divided by the weighted sum of inputs, while weights need to be assigned. To avoid the potential difficulty in assigning these weights among various DMUs, a DEA model computes weights that give the highest possible relative efficiency score to a DMU while keeping the efficiency scores of all DMUs less than or equal to one under the same set of weights (Liu et al., 2000). In recent years, DEA has been used to measure the efficiency of DMUs in many different settings, such as efficiency and effectiveness in operating management (Goncharuk, 2007; Parkan, 2006), supply chain management (Azadi and Farzipoor Saen, in press; Parkan and Wang, 2007; Wong et al., 2008), sport industry (Boscá et al., 2009; Cooper et al., 2009), construction industry (Baykasoglu et al., 2009; El-Mashaleh et al., 2010), farming industry (Mulwa et al., 2009) and banking industry (Azadeh et al., 2010; Cooper et al., 2008; Paradia et al., 2010).

In the standard use of DEA, it is supposed that one can, given a set of available factors, clearly determine which factors are inputs and which are outputs (Farzipoor Saen, in press). However, there is a strong argument for permitting certain factors to simultaneously play the role of both inputs and outputs in DEA models. For example, Beasley $(1990,1995)$, in a study of the efficiency of university departments, treated 'research income' on both the input and the output sides as a dual-role factor. Similar arguments can be made regarding the evaluation of suppliers, such as described in Farzipoor Saen (2010b) and Noorizadeh et al. (in press). There, research and development $(R \& D)$ cost is treated as dual-role factor. Suppliers R\&D cost clearly constitutes an output measure, but at the same time it is an important component of the supplier, hence it is an input. From the perspective of decision-maker who intends to select the best supplier, such measures may play the role of proxy for 'suppliers' innovation'. R\&D results in the technology that brings new products and services to the market place or strengthens better processes. Innovation results in high quality jobs, successful businesses, better goods and services and more efficient processes. That is why $R \& D$ can reasonably be classified as output. On the other hand, from the perspective of supplier, it can be considered as input that imposes special expenses to the supplier (Noorizadeh et al., in press). 
The objective of this paper is to propose an innovative approach for incorporating a dual-role factor in DEA models.

This paper proceeds as follows. In Section 2, literature review is presented. Section 3 introduces the proposed approach. A numerical example and managerial implications are discussed in Sections 4 and 5, respectively. Concluding remarks are given in Section 6.

\section{Literature review}

Beasley $(1990,1995)$, in a study of the efficiency of university departments, treated research funding on both the input and the output sides. However, as Cook et al. (2006) addressed, the model proposed by Beasley $(1990,1995)$ has two limitations. The first limitation is that in the absence of constraints (e.g. assurance region or cone ratio) on the multipliers, each DMU may be $100 \%$ efficient. The second limitation is that the dual-role factor is considered differently on the input than on the output side. Cook et al. (2006) developed a new model that has no above-mentioned limitations. Yang et al. (2010) analysed the structure and properties of the production systems and suggested a DEA model which considers dual-role factors. Farzipoor Saen (2010a) proposed a new model for selecting third-party reverse logistics (3PL) providers in the presence of multiple dual-role factors. In this paper, ratings for service-quality experience (EXP) and servicequality credence (CRE) are treated as dual-role factors. EXP and CRE could serve as either inputs or outputs. From the perspective of decision-maker who intends to select the best 3PL providers, such measures may play the role of proxy for 'high quality of services', hence can reasonably be classified as outputs. On the other hand, from the perspective of 3PL provider that intends to supply reverse logistics services, they can be considered as inputs that help the 3PL provider in obtaining more customers.

Farzipoor Saen (2010b) presented a method for selecting suppliers in the presence of dual-role factors and weight restrictions. In this paper, the R\&D cost was considered as both an input and an output. For selecting the best technologies in the presence of dualrole factors, Farzipoor Saen (2010c) considered the 'amount of personnel education hours by the robot supplier (RH)' as dual-role factor. Recently, Mahdiloo et al. (2011) addressed the problem of a factor in supplier selection analysis which may be classified either an input or an output. They demonstrated the validity of the proposed approach via comparing the results with conventional models. Farzipoor Saen (2010d) developed a new model for ranking 3PL providers in the presence of multiple dual-role factors. Cook and Zhu (2007) modified the standard constant returns to scale DEA model to treat dualrole factors. Both an individual DMU and an aggregate model were suggested as methodologies for deriving the most appropriate designations for dual-role factors. However, as Toloo addressed (2009), their method may produce incorrect efficiency scores due to a computational problem as a result of introducing a large positive number to the model. Toloo (2009) developed a model that does not need such a large positive number. Farzipoor Saen (in press) suggested a model for selecting media in the presence of both dual-role factors and imprecise data. This paper depicted the media selection process through a DEA model, while allowing for the incorporation of both dual-role factors and imprecise data. In his work, volume of supplied information to audiences was considered as a dual-role factor.

To the best of knowledge of authors, there is no reference dealing with a dual-role factor in a simplistic and straightforward way. 


\section{Proposed approach}

To evaluate the relative efficiency of the DMUs, there may exist a factor which can be classified as either an input or an output. The quantity of such a factor may influence the efficiency of the DMUs. To consider this dual-role factor, Beasley $(1990,1995)$ proposed Model (1) which is based on the standard Charnes, Cooper and Rhodes model (Charnes et al., 1978). Consider a situation where members $k$ of a set of $K$ DMUs are to be evaluated in terms of $R$ outputs $Y_{k}=\left(y_{r k}\right)_{r=1}^{R}$ and $I$ inputs $X_{k}=\left(x_{i k}\right)_{i=1}^{I}$. In addition, assume that a particular factor is held by each DMU in the amount $w_{k}$ and serves as both an input and an output factor.

$$
\begin{aligned}
& \operatorname{Max} \frac{\left(\sum_{r=1}^{R} \mu_{r} y_{r o}+\gamma w_{o}\right)}{\left(\sum_{i=1}^{I} v_{i} x_{i o}+\beta w_{o}\right)} \\
& \text { s.t. } \\
& \sum_{r=1}^{R} \mu_{r} y_{r k}+\gamma w_{k}-\sum_{i=1}^{I} v_{i} x_{i k}-\beta w_{k} \leq 0, \quad k=1, \ldots, K, \\
& \mu_{r}, v_{i}, \gamma, \beta \geq 0
\end{aligned}
$$

The used nomenclatures in this paper are summarised in Table 1.

Table 1 The nomenclatures

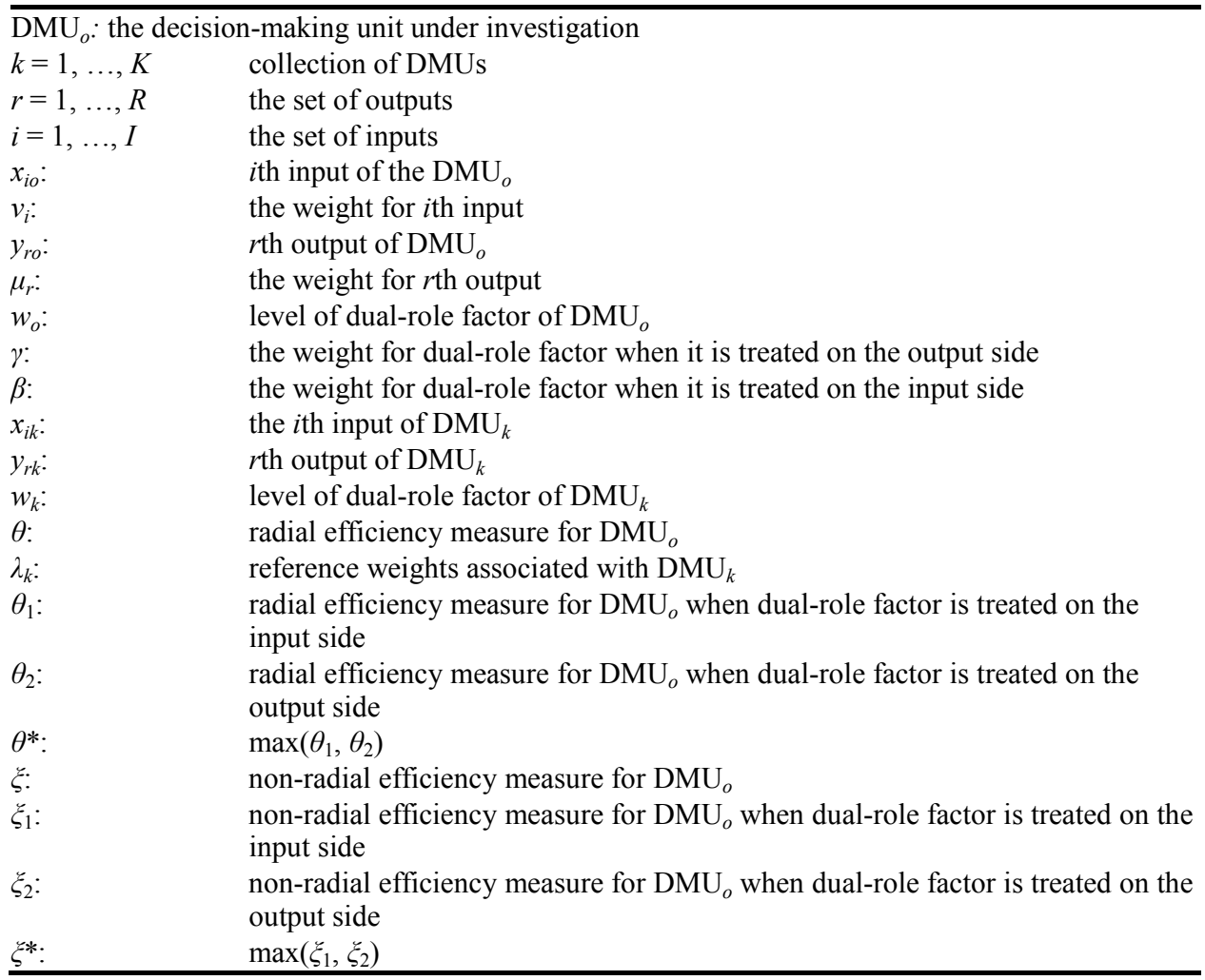


Cook et al. (2006) argue that Beasley's $(1990,1995)$ treatment of dual-role factor on both the input and the output sides is not entirely appropriate and represents somewhat of a contradiction.

Here, to show how this contradiction appears, consider input-oriented Model (2) which is the dual form of Model (1).

$$
\begin{aligned}
& \text { Min } \theta \\
& \text { s.t. } \\
& \sum_{k=1}^{K} x_{i k} \lambda_{k} \leq \theta x_{i o}, i=1, \ldots, I \\
& \sum_{k=1}^{K} w_{k} \lambda_{k} \leq \theta w_{o} \\
& \sum_{k=1}^{K} y_{r k} \lambda_{k} \geq y_{r o}, r=1, \ldots, R \\
& \sum_{k=1}^{K} w_{k} \lambda_{k} \geq w_{o} \\
& \lambda_{k} \geq 0 \\
& \theta \text { free }
\end{aligned}
$$

The logic of Model (2) is that in the case where a $\mathrm{DMU}_{o}$ has an efficiency score of $\theta$, then all discretionary inputs, including $w_{o}$, are reduced by $1-\theta$. On the other hand, this factor is also included on the output side where we assume $w_{o}$ will not be reduced. Thus, Models (1) and (2) treat $w_{o}$ differently on the input than on the output side. To correct this apparent flaw, Cook et al. (2006) recommend treating $w_{o}$ as being non-discretionary on the input side. Since, on the output side, variables generally remain fixed in the optimisation process of an input-oriented model, $w_{o}$ can be viewed as non-discretionary as well. From this perspective, Cook et al. (2006) modified Model (1) as below.

$$
\begin{aligned}
\operatorname{Max} & \sum_{r=1}^{R} \mu_{r} y_{r o}+\gamma w_{o}-\beta w_{o} \\
\text { s.t. } & \\
& \sum_{i=1}^{I} v_{i} x_{i o}=1 \\
& \sum_{r=1}^{R} \mu_{r} y_{r k}+\gamma w_{k}-\beta w_{k}-\sum_{i=1}^{I} v_{i} x_{i k} \leq 0, \quad k=1, \ldots, K, \\
& \mu_{r}, v_{i}, \gamma, \beta \geq 0
\end{aligned}
$$

The inclusion of the dual-role factor on the input side of Model (3) as a non-discretionary input is based on the idea of Banker and Morey (1986). The authors prove that the way to model such inputs is to move them to the output side but with the opposite sign. This idea often arises in situations where there are criteria that are beyond the control of the management but influence the efficiency of DMUs. Thus, in evaluating process, these factors are generally expected to remain at their current level. 
Now, one of the three possibilities exists in regard to the sign of $\hat{\gamma}-\hat{\beta}$, where $\hat{\gamma}$ and $\hat{\beta}$ are the optimal values from $\operatorname{Model}(3) ; \hat{\gamma}-\hat{\beta}>0,=0$ or $<0$ (Cook et al., 2006).

Case 1 If $\hat{\gamma}-\hat{\beta}<0$, then the dual-role factor is 'behaving like input'. Hence, less of this factor is better and would lead to an increase in efficiency.

Case 2 If $\hat{\gamma}-\hat{\beta}>0$, then the dual-role factor is 'behaving like output'. Hence, more of this factor is better and would lead to an increase in efficiency.

Case 3 If $0 \hat{\gamma}-\hat{\beta}=0$, then dual-role factor is at equilibrium level.

However, Model (3) suffers from three limitations:

1 Classifying a factor as an input or an output within a single model cannot guarantee that the production function and the causality relationship between inputs and outputs are verified. That is, considering a factor as an input and an output in a single model means that there is a factor that is used to produce itself.

2 They considered dual-role factor as non-discretionary factor. However, in real-world applications, dual-role factor may be as a discretionary factor.

3 In DEA, non-zero input and output slacks are very likely to reveal themselves after the radial efficiency score improvement. Often, the non-zero slack values reveal a considerable amount of inefficiency. Therefore, to fully measure the inefficiency in DMU's performance, it is crucial to consider the inefficiency represented by the nonzero slacks in the presence of dual-role factors. However, all the models used in the past, which consider dual-role factor, are radial models and cannot fully measure the inefficiency of DMUs.

At this juncture, we introduce an innovative approach to treat with a dual-role factor and to determine the behaviour of this factor as input, output or equilibrium. This new approach does not suffer from the first limitation of Model (3) discussed above. That is, it considers the causality relationship between inputs and outputs and does not classify a factor as an input and an output within a single model.

Model (4) treats dual-role factor only on the input side and as a non-discretionary input. ${ }^{1}$

Min $\theta_{1}$

$$
\begin{aligned}
& \text { s.t. } \\
& \sum_{k=1}^{K} x_{i k} \lambda_{k} \leq \theta_{1} x_{i o}, \quad i=1, \ldots, I \\
& \sum_{k=1}^{K} w_{k} \lambda_{k} \leq w_{o} \\
& \sum_{k=1}^{K} y_{r k} \lambda_{k} \geq y_{r o}, \quad r=1, \ldots, R \\
& \lambda_{k} \geq 0 \\
& \theta_{1} \text { free }
\end{aligned}
$$


Model (5) treats dual-role factor only on the output side.

$$
\begin{array}{ll}
\operatorname{Min} & \theta_{2} \\
\text { s.t. } & \\
\sum_{k=1}^{K} x_{i k} \lambda_{k} \leq \theta_{2} x_{i o}, \quad i=1, \ldots, I \\
\sum_{k=1}^{K} y_{r k} \lambda_{k} \geq y_{r o}, \quad r=1, \ldots, R \\
\sum_{k=1}^{K} w_{k} \lambda_{k} \geq w_{o} \\
\lambda_{k} \geq 0 \\
\theta_{2} \text { free }
\end{array}
$$

Table 2 illustrates the algorithm of this new approach.

So far, by using the new algorithm, the first limitation of Model (3) has been resolved. However, in this new approach, to treat $w_{o}$ on both input and output sides in a same manner, dual-role factor is incorporated as a non-discretionary input on the input side. Therefore, the second and third limitations of Model (3) remain. Now, the second limitation is discussed.

As mentioned before, Model (1) treats $w_{o}$ differently on the input than on the output side. To correct this problem of Model (1), Cook et al. (2006) recommend treating $w_{o}$ as being non-discretionary on the input side. Although this treatment eliminates the contradiction occurred in Model (1), but this approach itself make a new and apparent contradiction. Consider research income as a non-discretionary factor. It means that this factor is beyond the control of management; hence, we should not blame management of DMU which has a weak performance on this special factor. Here a question arises. Is the dual-role a non-discretionary factor in all situations? The response is that there might be some situations that a dual-role is a discretionary factor. Therefore, we need a model that not only treats $w_{o}$ on both the input and the output sides in a same manner discussed in Cook et al. (2006), but also considers it as a discretionary factor.

Table 2 Algorithm of the proposed approach

Step 1 Start

Step 2 Treat dual-role factor only on the input side and run Model (4)

Step 3 Treat dual-role factor on the output side and run Model (5)

Step 4 Find $\max \left(\theta_{1}, \theta_{2}\right)=\theta^{*}$ and consider it as the efficiency score of $\mathrm{DMU}_{o}$

Step 5 Now, consider $\theta_{1}, \theta_{2}$ as an indicator of dual-role factor's behaviour as well. The $\theta_{1}, \theta_{2}$ are interpreted as below ${ }^{\mathrm{a}}$

Case 1 If, $\theta_{1}>\theta_{2}$, then the dual-role factor is 'behaving as input'

Case 2 If $\theta_{1}<\theta_{2}$, then the dual-role factor is 'behaving as output'

Case 3 If $\theta_{1}=\theta_{2}$, then the dual-role factor is at equilibrium level

${ }^{a}$ Since DEA computes weights that give the highest possible relative efficiency score to a DMU while keeping the efficiency scores of all DMUs less than or equal to one under the same set of weights, so we select $\max \left(\theta_{1}, \theta_{2}\right)$ as the indicator of dual-role factor's behaviour. 
The above models are all radial measures which are oriented on the input side (inputoriented) or on the output side (output-oriented) which causes different treatment on the input than on the output side or vice versa.

Now, we use slacks-based measure (SBM) model introduced by Tone (2001) and incorporate the concept of dual-role factor in this model. Since SBM is a non-oriented model, so it has the capability of treating $w_{o}$ on both the input and the output sides in a same manner. Model (6) shows the original SBM model proposed by Tone (2001).

$\operatorname{Max} \xi$

$$
\begin{aligned}
& \text { s.t. } \\
& \begin{array}{l}
\xi+\sum_{i=1}^{I} v_{i} x_{i o}-\sum_{r=1}^{R} \mu_{r} y_{r o}=1 \\
-\sum_{i=1}^{I} v_{i} x_{i k}+\sum_{r=1}^{R} \mu_{r} y_{r k} \leq 0, \quad k=1, \ldots, K \\
v_{i} \geq \frac{1}{I}\left[\frac{1}{x_{i o}}\right], \quad i=1, \ldots, I \\
\mu_{r} \geq \frac{\xi}{R}\left[\frac{1}{y_{r o}}\right], \quad r=1, \ldots, R
\end{array}
\end{aligned}
$$

Model (7) is a SBM model which measures the efficiency of $\mathrm{DMU}_{o}$ by incorporating dual-role factor in the input side.

$\operatorname{Max} \xi_{1}$

$$
\begin{aligned}
& \text { s.t. } \\
& \xi_{1}+\sum_{i=1}^{I} v_{i} x_{i o}+\beta w_{o}-\sum_{r=1}^{R} \mu_{r} y_{r o}=1 \\
& -\left(\sum_{i=1}^{I} v_{i} x_{i k}+\beta w_{k}\right)+\sum_{r=1}^{R} \mu_{r} y_{r k} \leq 0, \quad k=1, \ldots, K \\
& v_{i} \geq \frac{1}{I+1}\left[\frac{1}{x_{i o}}\right], \quad i=1, \ldots, I \\
& \beta \geq \frac{1}{I+1}\left[\frac{1}{w_{o}}\right] \\
& \mu_{r} \geq \frac{\xi_{1}}{R}\left[\frac{1}{y_{r o}}\right], \quad r=1, \ldots, R
\end{aligned}
$$


Model (8) is a SBM model which incorporates dual-role factor on the output side. ${ }^{2}$

$$
\begin{array}{ll}
\operatorname{Max} & \xi_{2} \\
\text { s.t. } & \\
& \xi_{2}+\sum_{i=1}^{I} v_{i} x_{i o}-\sum_{r=1}^{R} \mu_{r} y_{r o}+\gamma w_{o}=1 \\
& -\sum_{i=1}^{I} v_{i} x_{i k}+\sum_{r=1}^{R} \mu_{r} y_{r k}+\gamma w_{k} \leq 0, \quad k=1, \ldots, K \\
& v_{i} \geq \frac{1}{I}\left[\frac{1}{x_{i o}}\right], \quad i=1, \ldots, I \\
& \mu_{r} \geq \frac{\xi_{2}}{R+1}\left[\frac{1}{y_{r o}}\right], \quad r=1, \ldots, R \\
& \gamma \geq \frac{1}{R+1}\left[\frac{1}{w_{o}}\right]
\end{array}
$$

Note that, Models (7) and (8) are both non-radial and non-oriented. Therefore, they have two important features:

1 they do not need to incorporate dual-role as a non-discretionary factor on the input side

2 they can fully measure the inefficiency of DMUs.

Therefore, by using Models (7) and (8), all the three limitations of Model (3) are obviated.

\subsection{Contingency table}

In this section, we apply a statistical technique to determine the association between the results of Cook et al. (2006) and the new suggested approach in determining the behaviour of dual-role factor.

Since the behaviour of dual-role factor in Model (3) and the proposed algorithm is recorded in three sets of mutually exclusive and exhaustive categories, it is possible to construct a cross tabulation or contingency table. In the analysis of categorical data, the cross tabulation is the analogue of the scatter plot. In the case of nominal data, chisquare-based statistics ( $\varphi$, Cramer's $V$ and contingency coefficient) should be used, which are used for determining the presence of an association between qualitative variables. An ideal measure should mimic the correlation coefficient by having a maximum absolute value of 1 for perfect association, and a value of 0 for no association. The choice of the appropriate statistic depends on whether the variables are ordinal or nominal, and whether the contingency (cross tabulation) table is $2 \times 2$ (each variable has two categories) or larger. For example, one such statistic is the $\varphi$ coefficient obtained by dividing the value of chi-square by the total frequency and taking the square root. For two-way contingency tables involving variables with more than two categories (such as our case which the behaviour of dual-role factor categorised in $k_{1}, k_{2}$ and $k_{3}$ ), however, another statistic, known as Cramer's $V$, is preferred because with more complex tables, 
Cramer's measure can still, as in the $2 \times 2$ case, achieve its maximum value of unity (Kinnear and Gray, 1994).

In Section 4, a numerical example is presented. In this example, we examine the ability of our proposed approach in determining the efficiency scorers of DMUs and the behaviour of dual-role factor.

\section{Numerical example}

As discussed in Section 2, considering the dual-role factor as a non-discretionary factor is incorrect. However, to compare our approach with Cook et al. (2006), we first have to consider the dual-role factor as a non-discretionary factor. So before using the final proposed approach (Models (7) and (8)), we use Models (4) and (5) to compare universities as discussed in Beasley $(1990,1995)$ and Cook et al. (2006). Beasley evaluates the efficiency scores of both Chemistry and Physics Departments at 50 UK universities. Table 3 displays a portion of the data for Physics Department, recreated from Beasley (1990). As well, Cook et al. (2006) used these data to examine the modelling of dual-role factors in their proposed model (Model (3)). Inputs are general expenditure $\left(x_{1}\right)$ and equipment expenditure $\left(x_{2}\right)$. Outputs consist of three student groups $\left(y_{1}, y_{2}\right.$ and $\left.y_{3}\right)$. And research income $(w)$ simultaneously plays the role of both input and output.

Tables 4 and 5 show the results of the evaluation by Model (3) and our proposed radial approach (Models (4) and (5)), respectively. The results in Table 4 imply that $k_{1}=31, k_{2}=16$ and $k_{3}=3$. DMUs in $k_{1}$ are those wherein the research income is behaving like an output, and where more of such income would improve the efficiencies of the members of that set. For those DMUs in $k_{2}$, research income is behaving like an input, and less of such factor would increase the efficiency of the members. The three universities in $k_{3}$ are in equilibrium.

In Table 5, $\theta_{1}$ shows the radial efficiency score of $\mathrm{DMU}_{o}$ derived by Model (4), that the research income is treated on the input side and as a non-discretionary input. The $\theta_{2}$ shows the radial efficiency score of $\mathrm{DMU}_{o}$ by using Model (5), that the research income is treated on the output side. The $\theta^{*}$ is the final radial efficiency score of $\mathrm{DMU}_{o}$ derived by $\max \left(\theta_{1}, \theta_{2}\right)$.

The results derived by Model (3) and our proposed approach consist of two parts: efficiency scores and behaviour of dual-role factor. Part one is as below.

Since the efficiency scores derived by two methods are exactly the same, this validates our proposed approach as an efficiency measurement tool. As a result, as you see, our proposed approach is a simple and straightforward algorithm to evaluate the efficiency of DMUs in the presence of dual-role factor.

Part two is as follows. To compare the behaviour of dual-role factor, we construct a contingency table. Since we have a two-way contingency table involving variables with three categories $\left(k_{1}, k_{2}\right.$ and $\left.k_{3}\right)$, so statistic known as Cramer's $V$ is used for determining the association between two groups (as recommended by Kinnear and Gray, 1994). The null hypothesis $\left(H_{0}\right)$ is that there is no association between the behaviour of dual-role factor in Model (3) and our proposed approach. Table 6 depicts the contingency table. The values of the table are frequencies. 
Table 7 displays the statistics of contingency table using SPSS software.

Table 3 Data for Physics Departments from Beasley (1990)

\begin{tabular}{|c|c|c|c|c|c|c|}
\hline$D M U s$ & $x_{1}$ & $x_{2}$ & $y_{1}$ & $y_{2}$ & $y_{3}$ & $W$ \\
\hline University 1 & 528 & 64 & 145 & 0 & 26 & 254 \\
\hline University 2 & 2,605 & 301 & 381 & 16 & 54 & 1,485 \\
\hline University 3 & 304 & 23 & 44 & 3 & 3 & 45 \\
\hline University 4 & 1,620 & 485 & 287 & 0 & 48 & 940 \\
\hline University 5 & 490 & 90 & 91 & 8 & 22 & 106 \\
\hline University 6 & 2,675 & 767 & 352 & 4 & 166 & 2,967 \\
\hline University 7 & 422 & 0 & 70 & 12 & 19 & 298 \\
\hline University 8 & 986 & 126 & 203 & 0 & 32 & 776 \\
\hline University 9 & 523 & 32 & 60 & 0 & 17 & 39 \\
\hline University 10 & 585 & 87 & 80 & 17 & 27 & 353 \\
\hline University 11 & 931 & 161 & 191 & 0 & 20 & 293 \\
\hline University 12 & 1,060 & 91 & 139 & 0 & 37 & 781 \\
\hline University 13 & 500 & 109 & 104 & 0 & 19 & 215 \\
\hline University 14 & 714 & 77 & 132 & 0 & 24 & 269 \\
\hline University 15 & 923 & 121 & 135 & 10 & 31 & 392 \\
\hline University 16 & 1,267 & 128 & 169 & 0 & 31 & 546 \\
\hline University 17 & 891 & 116 & 125 & 0 & 24 & 925 \\
\hline University 18 & 1,395 & 571 & 176 & 14 & 27 & 764 \\
\hline University 19 & 990 & 83 & 28 & 36 & 57 & 615 \\
\hline University 20 & 3,512 & 267 & 511 & 23 & 153 & 3,182 \\
\hline University 21 & 1,451 & 226 & 198 & 0 & 53 & 791 \\
\hline University 22 & 1,018 & 81 & 161 & 5 & 29 & 741 \\
\hline University 23 & 1,115 & 450 & 148 & 4 & 32 & 347 \\
\hline University 24 & 2,055 & 112 & 207 & 1 & 47 & 2,945 \\
\hline University 25 & 440 & 74 & 115 & 0 & 9 & 453 \\
\hline University 26 & 3,897 & 841 & 353 & 28 & 65 & 2,331 \\
\hline University 27 & 836 & 81 & 129 & 0 & 37 & 695 \\
\hline University 28 & 1,007 & 50 & 174 & 7 & 23 & 98 \\
\hline University 29 & 1,188 & 170 & 253 & 0 & 38 & 879 \\
\hline University 30 & 4,630 & 628 & 544 & 0 & 217 & 4,838 \\
\hline University 31 & 977 & 77 & 94 & 26 & 26 & 490 \\
\hline University 32 & 829 & 61 & 128 & 17 & 25 & 291 \\
\hline University 33 & 898 & 39 & 190 & 1 & 18 & 327 \\
\hline University 34 & 901 & 131 & 168 & 9 & 50 & 956 \\
\hline University 35 & 924 & 119 & 119 & 37 & 48 & 512 \\
\hline University 36 & 1,251 & 62 & 193 & 13 & 43 & 563 \\
\hline
\end{tabular}


Table 3 Data for Physics Departments from Beasley (1990) (continued)

\begin{tabular}{lcccccc}
\hline DMUs & $x_{1}$ & $x_{2}$ & $y_{1}$ & $y_{2}$ & $y_{3}$ & $W$ \\
\hline University 37 & 1,011 & 235 & 217 & 0 & 36 & 714 \\
University 38 & 732 & 94 & 151 & 3 & 23 & 297 \\
University 39 & 444 & 46 & 49 & 2 & 19 & 277 \\
University 40 & 308 & 28 & 57 & 0 & 7 & 154 \\
University 41 & 483 & 40 & 117 & 0 & 23 & 531 \\
University 42 & 515 & 68 & 79 & 7 & 23 & 305 \\
University 43 & 593 & 82 & 101 & 1 & 9 & 85 \\
University 44 & 570 & 26 & 71 & 20 & 11 & 130 \\
University 45 & 1,317 & 123 & 293 & 1 & 39 & 1,043 \\
University 46 & 2,013 & 149 & 403 & 2 & 51 & 1,523 \\
University 47 & 992 & 89 & 161 & 1 & 30 & 743 \\
University 48 & 1,038 & 82 & 151 & 13 & 47 & 513 \\
University 49 & 206 & 1 & 16 & 0 & 6 & 72 \\
University 50 & 1,193 & 95 & 240 & 0 & 32 & 485 \\
\hline
\end{tabular}

Table 4 Efficiency scores and output/input behaviour using Model (3)

\begin{tabular}{lcc}
\hline DMUS & Efficiency & Behaviour \\
\hline University 1 & 1.000 & $k_{2}$ \\
University 2 & 0.640 & $k_{1}$ \\
University 3 & 0.810 & $k_{2}$ \\
University 4 & 0.686 & $k_{1}$ \\
University 5 & 1.000 & $k_{2}$ \\
University 6 & 1.000 & $k_{1}$ \\
University 7 & 1.000 & $k_{1}$ \\
University 8 & 0.812 & $k_{1}$ \\
University 9 & 1.000 & $k_{2}$ \\
University 10 & 0.907 & $k_{1}$ \\
University 11 & 0.828 & $k_{2}$ \\
University 12 & 0.709 & $k_{1}$ \\
University 13 & 0.772 & $k_{1}$ \\
University 14 & 0.703 & $k_{2}$ \\
University 15 & 0.688 & $k_{1}$ \\
University 16 & 0.520 & $k_{1}$ \\
University 17 & 0.819 & $k_{1}$ \\
University 18 & 0.628 & $k_{1}$ \\
\hline & & \\
\hline
\end{tabular}


Table 4 Efficiency scores and output/input behaviour using Model (3) (continued)

\begin{tabular}{|c|c|c|}
\hline$D M U s$ & Efficiency & Behaviour \\
\hline University 19 & 1.000 & $k_{1}$ \\
\hline University 20 & 0.898 & $k_{1}$ \\
\hline University 21 & 0.674 & $k_{2}$ \\
\hline University 22 & 0.717 & $k_{1}$ \\
\hline University 23 & 0.563 & $k_{2}$ \\
\hline University 24 & 1.000 & $k_{1}$ \\
\hline University 25 & 1.000 & $k_{1}$ \\
\hline University 26 & 0.565 & $k_{1}$ \\
\hline University 27 & 0.855 & $k_{1}$ \\
\hline University 28 & 1.000 & $k_{2}$ \\
\hline University 29 & 0.825 & $k_{1}$ \\
\hline University 30 & 0.930 & $k_{1}$ \\
\hline University 31 & 0.776 & $k_{1}$ \\
\hline University 32 & 0.867 & $k_{2}$ \\
\hline University 33 & 1.000 & $k_{3}$ \\
\hline University 34 & 1.000 & $k_{1}$ \\
\hline University 35 & 1.000 & $k_{1}$ \\
\hline University 36 & 0.737 & $k_{2}$ \\
\hline University 37 & 0.831 & $k_{1}$ \\
\hline University 38 & 0.806 & $k_{1}$ \\
\hline University 39 & 0.790 & $k_{2}$ \\
\hline University 40 & 0.741 & $k_{1}$ \\
\hline University 41 & 1.000 & $k_{1}$ \\
\hline University 42 & 0.841 & $k_{2}$ \\
\hline University 43 & 0.900 & $k_{2}$ \\
\hline University 44 & 1.000 & $k_{3}$ \\
\hline University 45 & 0.889 & $k_{1}$ \\
\hline University 46 & 0.851 & $k_{3}$ \\
\hline University 47 & 0.688 & $k_{1}$ \\
\hline University 48 & 0.909 & $k_{2}$ \\
\hline University 49 & 1.000 & $k_{2}$ \\
\hline University 50 & 0.835 & $k_{1}$ \\
\hline
\end{tabular}


Table 5 Efficiency scores and output/input behaviour using Models (4) and (5)

\begin{tabular}{|c|c|c|c|c|}
\hline$D M U s$ & $\theta_{1}$ & $\theta_{2}$ & $\theta^{*}$ & Behaviour \\
\hline University 1 & 1.000 & 1.000 & 1.000 & $k_{3}$ \\
\hline University 2 & 0.615 & 0.640 & 0.640 & $k_{1}$ \\
\hline University 3 & 0.810 & 0.663 & 0.810 & $k_{2}$ \\
\hline University 4 & 0.645 & 0.686 & 0.686 & $k_{1}$ \\
\hline University 5 & 1.000 & 0.893 & 1.000 & $k_{2}$ \\
\hline University 6 & 1.000 & 1.000 & 1.000 & $k_{3}$ \\
\hline University 7 & 1.000 & 1.000 & 1.000 & $k_{3}$ \\
\hline University 8 & 0.750 & 0.812 & 0.812 & $k_{1}$ \\
\hline University 9 & 1.000 & 0.658 & 1.000 & $k_{2}$ \\
\hline University 10 & 0.892 & 0.907 & 0.907 & $k_{1}$ \\
\hline University 11 & 0.828 & 0.747 & 0.828 & $k_{2}$ \\
\hline University 12 & 0.690 & 0.709 & 0.709 & $k_{1}$ \\
\hline University 13 & 0.767 & 0.772 & 0.772 & $k_{1}$ \\
\hline University 14 & 0.703 & 0.702 & 0.703 & $k_{2}$ \\
\hline University 15 & 0.676 & 0.688 & 0.688 & $k_{1}$ \\
\hline University 16 & 0.518 & 0.520 & 0.520 & $k_{1}$ \\
\hline University 17 & 0.536 & 0.819 & 0.819 & $k_{1}$ \\
\hline University 18 & 0.593 & 0.628 & 0.628 & $k_{1}$ \\
\hline University 19 & 1.000 & 1.000 & 1.000 & $k_{3}$ \\
\hline University 20 & 0.858 & 0.898 & 0.898 & $k_{1}$ \\
\hline University 21 & 0.674 & 0.669 & 0.674 & $k_{2}$ \\
\hline University 22 & 0.664 & 0.717 & 0.717 & $k_{1}$ \\
\hline University 23 & 0.563 & 0.560 & 0.563 & $k_{2}$ \\
\hline University 24 & 0.484 & 1.000 & 1.000 & $k_{1}$ \\
\hline University 25 & 0.952 & 1.000 & 1.000 & $k_{1}$ \\
\hline University 26 & 0.425 & 0.565 & 0.565 & $k_{1}$ \\
\hline University 27 & 0.852 & 0.855 & 0.855 & $k_{1}$ \\
\hline University 28 & 1.000 & 0.809 & 1.000 & $k_{2}$ \\
\hline University 29 & 0.775 & 0.825 & 0.825 & $k_{1}$ \\
\hline University 30 & 0.831 & 0.930 & 0.930 & $k_{1}$ \\
\hline University 31 & 0.728 & 0.776 & 0.776 & $k_{1}$ \\
\hline University 32 & 0.867 & 0.841 & 0.867 & $k_{2}$ \\
\hline University 33 & 1.000 & 1.000 & 1.000 & $k_{3}$ \\
\hline University 34 & 1.000 & 1.000 & 1.000 & $k_{3}$ \\
\hline University 35 & 1.000 & 1.000 & 1.000 & $k_{3}$ \\
\hline University 36 & 0.737 & 0.735 & 0.737 & $k_{2}$ \\
\hline
\end{tabular}


Table 5 Efficiency scores and output/input behaviour using Models (4) and (5) (continued)

\begin{tabular}{lcccc}
\hline DMUs & $\theta_{1}$ & $\theta_{2}$ & $\theta^{*}$ & Behaviour \\
\hline University 37 & 0.782 & 0.831 & 0.831 & $k_{1}$ \\
University 38 & 0.806 & 0.806 & 0.806 & $k_{3}$ \\
University 39 & 0.790 & 0.789 & 0.790 & $k_{2}$ \\
University 40 & 0.740 & 0.741 & 0.741 & $k_{1}$ \\
University 41 & 1.000 & 1.000 & 1.000 & $k_{3}$ \\
University 42 & 0.841 & 0.835 & 0.841 & $k_{2}$ \\
University 43 & 0.900 & 0.643 & 0.900 & $k_{2}$ \\
University 44 & 1.000 & 1.000 & 1.000 & $k_{3}$ \\
University 45 & 0.883 & 0.889 & 0.889 & $k_{1}$ \\
University 46 & 0.848 & 0.851 & 0.851 & $k_{1}$ \\
University 47 & 0.655 & 0.688 & 0.688 & $k_{1}$ \\
University 48 & 0.909 & 0.883 & 0.909 & $k_{2}$ \\
University 49 & 1.000 & 0.637 & 1.000 & $k_{2}$ \\
University 50 & 0.835 & 0.835 & 0.835 & $k_{3}$ \\
\hline
\end{tabular}

Table 6 Contingency table

\begin{tabular}{llcccc}
\hline Proposed approach & \multicolumn{5}{c}{ Model (3) } \\
\cline { 2 - 6 } & \multicolumn{1}{c}{$k_{1}$} & $k_{2}$ & $k_{3}$ & Summation \\
\cline { 2 - 6 } & $k_{1}$ & 23 & 0 & 8 & 31 \\
$k_{2}$ & 0 & 15 & 1 & 16 \\
& $k_{3}$ & 1 & 0 & 2 & 3 \\
& Summation & 24 & 15 & 11 & 50 \\
\hline
\end{tabular}

Table 7 Statistics of contingency table

\begin{tabular}{lcc}
\hline & Value & Approximate significance \\
\hline Cramer's $V$ & 0.699 & 0.000 \\
No. of valid cases & 50 & \\
\hline
\end{tabular}

It can be concluded that there is a significant association between the results of two models in determining the behaviour of dual-role factor, as shown by the last column of Table $7(<0.01)$. Cramer's $V$ coefficient provides a measure of the strength of the association.

Now, after demonstrating real nature of the proposed approach statistically, the final models (Models (7) and (8)) are used to evaluate the efficiency score of universities. The results are shown in Table 8 . In this table, the $\xi_{1}$ shows the non-radial efficiency score of $\mathrm{DMU}_{o}$ derived by Model (7), where research income is treated as the input. The $\xi_{2}$ indicates the non-radial efficiency score of $\mathrm{DMU}_{o}$ derived by Model (8), where research income is treated as the output. The $\xi^{*}$ is the final non-radial efficiency score of $\mathrm{DMU}_{o}$ determined by $\max \left(\xi_{1}, \xi_{2}\right)$. $^{3}$ 
By comparing the efficiency scores derived by radials Models (3)-(5) with non-radial Models (7) and (8), it can be easily seen that radial models including conventional models, which consider dual-role factors, are not able to fully measure the inefficiencies of inefficient DMUs.

The visual computational results obtained by Models (7) and (8) and the final efficiency score of DMUs $\left(\xi^{*}\right)$ are presented in Figure 1. This figure has two coordinates (university and efficiency) and shows the efficiency of the 50 universities under consideration. As shown, efficiency scores for the efficient universities are one and the efficiency scores of all the remaining universities are less than one.

Table 8 Efficiency scores and output/input behaviour using Models (7) and (8)

\begin{tabular}{|c|c|c|c|}
\hline$D M U s$ & $\xi_{1}$ & $\xi_{2}$ & $\xi^{*}$ \\
\hline University 1 & 1 & 1 & 1 \\
\hline University 2 & 0.2625 & 0.218 & 0.2625 \\
\hline University 3 & 0.5188 & 0.1497 & 0.5188 \\
\hline University 4 & 0.0005 & 0.0005 & 0.0005 \\
\hline University 5 & 1 & 0.3172 & 1 \\
\hline University 6 & 1 & 1 & 1 \\
\hline University 7 & 1 & 1 & 1 \\
\hline University 8 & 0.0012 & 0.0018 & 0.0018 \\
\hline University 9 & 1 & 0.0013 & 1 \\
\hline University 10 & 0.7384 & 0.4907 & 0.7384 \\
\hline University 11 & 0.0021 & 0.0015 & 0.0021 \\
\hline University 12 & 0.0006 & 0.0007 & 0.0007 \\
\hline University 13 & 0.0029 & 0.0028 & 0.0029 \\
\hline University 14 & 0.0017 & 0.0014 & 0.0017 \\
\hline University 15 & 0.4871 & 0.2958 & 0.4871 \\
\hline University 16 & 0.0005 & 0.0006 & 0.0006 \\
\hline University 17 & 0.0006 & 0.0018 & 0.0018 \\
\hline University 18 & 0.2804 & 0.2576 & 0.2804 \\
\hline University 19 & 1 & 1 & 1 \\
\hline University 20 & 0.2731 & 0.4911 & 0.4911 \\
\hline University 21 & 0.0004 & 0.0005 & 0.0005 \\
\hline University 22 & 0.2312 & 0.2216 & 0.2312 \\
\hline University 23 & 0.1861 & 0.1537 & 0.1861 \\
\hline University 24 & 0.0241 & 1 & 1 \\
\hline University 25 & 0.0134 & 1 & 1 \\
\hline University 26 & 0.2148 & 0.2069 & 0.2148 \\
\hline University 27 & 0.0008 & 0.0013 & 0.0013 \\
\hline University 28 & 1 & 0.1608 & 1 \\
\hline
\end{tabular}


Table 8 Efficiency scores and output/input behaviour using Models (7) and (8) (continued)

\begin{tabular}{|c|c|c|c|}
\hline$D M U_{s}$ & $\xi_{1}$ & $\xi_{2}$ & $\xi^{*}$ \\
\hline University 29 & 0.0011 & 0.0016 & 0.0016 \\
\hline University 30 & 0.0001 & 0.0005 & 0.0005 \\
\hline University 31 & 0.5534 & 0.3395 & 0.5534 \\
\hline University 32 & 0.7852 & 0.3354 & 0.7852 \\
\hline University 33 & 1 & 1 & 1 \\
\hline University 34 & 1 & 1 & 1 \\
\hline University 35 & 1 & 1 & 1 \\
\hline University 36 & 0.5649 & 0.2991 & 0.5649 \\
\hline University 37 & 0.0013 & 0.0017 & 0.0017 \\
\hline University 38 & 0.4262 & 0.3224 & 0.4262 \\
\hline University 39 & 0.2398 & 0.2 & 0.2398 \\
\hline University 40 & 0.0037 & 0.0034 & 0.0037 \\
\hline University 41 & 1 & 1 & 1 \\
\hline University 42 & 0.5528 & 0.3722 & 0.5528 \\
\hline University 43 & 0.2506 & 0.0828 & 0.2506 \\
\hline University 44 & 1 & 1 & 1 \\
\hline University 45 & 0.1176 & 0.1909 & 0.1909 \\
\hline University 46 & 0.1051 & 0.1402 & 0.1402 \\
\hline University 47 & 0.0619 & 0.0692 & 0.0692 \\
\hline University 48 & 0.7108 & 0.3506 & 0.7108 \\
\hline University 49 & 1 & 0.0034 & 1 \\
\hline University 50 & 0.0014 & 0.0013 & 0.0014 \\
\hline
\end{tabular}

Figure 1 Visual results of the computations

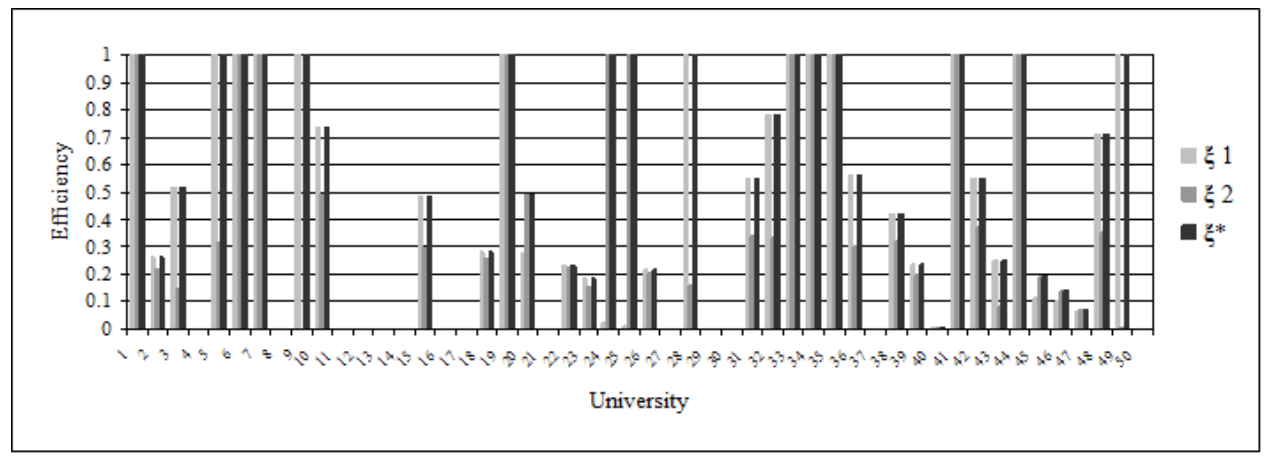




\section{Managerial implications}

All conventional DEA models which consider dual-role factors are radial models. In DEA, non-zero input and output slacks are very likely to reveal themselves after the radial efficiency score improvement. Often, the non-zero slack values reveal a considerable amount of inefficiency. Therefore, to fully measure the inefficiency in performance of DMUs, it is crucial to consider the inefficiency represented by the nonzero slacks in the presence of dual-role factors. Dual-role factors play the role of both inputs and outputs in DEA models, simultaneously. In addition, conventional DEA models deal with dual-role factors as non-discretionary factors. However, there might be dual-role factors which are completely discretionary. Decision variable is an important element in DEA framework, and the cognition of decision variable improves the progress of DEA-based theories and approaches (Yang et al., 2010). Farzipoor Saen (in press) addresses that, in traditional DEA, the decision-maker decides which criteria are inputs and which are outputs. However, in the dual-role factor context, the decision-maker is wavered. In other words, the decision-maker does not know whether this dual-role factor is an input or an output. Therefore, there is a need for a model that determines the status of the dual-role factor for each DMU, separately. After running the model, the decisionmaker will find the status of the dual-role factor.

\section{Concluding remarks}

This paper addressed the problem of a factor in a DEA analysis which may be classified as either an input or an output. The quantity of such a factor may influence the relative efficiency of the DMUs. Such problems have been discussed in the literature before. However, the main contribution of this paper is to consider a dual-role factor as a discretionary variable and to analyse it in the context of a SBM. The validity of the proposed approach is demonstrated via comparing the results with results of previous model using a contingency table. A two-way contingency table and a statistic known as Cramer's $V$ were applied to check the significance association between the results of proposed approach and Cook et al. (2006). The approach presented in this paper has some distinctive contributions, as follows:

- the proposed approach is very simple and straightforward

- the proposed approach can be easily used in each kind of DEA models without any effort to combine concept of dual-role factor with these models

- the proposed approach does not deal with dual-role factor as a non-discretionary factor

- this is the first time that dual-role factor and SBM are discussed simultaneously

- this is the first time that results of DEA analysis are compared by means of a statistical technique, i.e. contingency table. 
The problem considered in this study is at initial stage of investigation and further researches can be done based on the results of this paper. Some of them are as below:

- Since in the proposed approach each DMU is free to decide which outputs and inputs to emphasise, there may exist many efficient DMUs. Therefore, the proposed approach should be developed to rank efficient DMUs.

- The proposed algorithm can be used in the presence of imprecise data.

- In any realistic situation there may exist some criteria that are beyond the control of the management. These factors are called non-discretionary or exogenously fixed factors. Similar research can be repeated for the evaluation of DMUs in the presence of non-discretionary factors.

- Preferences of decision-maker can be incorporated into the proposed algorithm by restricting the feasible region of the inputs and outputs' weights.

\section{Acknowledgement}

The authors wish to thank the anonymous reviewer for valuable suggestions and comments.

\section{References}

Azadeh, A., Ghaderi, S.F., Mirjalili, M. and Moghaddam, M. (2010) 'A DEA approach for ranking and optimisation of technical and management efficiency of a large bank based on financial indicators', Int. J. Operational Research, Vol. 9, No. 2, pp.160-187.

Azadi, M. and Farzipoor Saen, R. (in press) 'Developing a new chance-constrained DEA model for suppliers selection in the presence of undesirable outputs', Int. J. Operational Research.

Banker, R.D. and Morey, R.C. (1986) 'Efficiency analysis for exogenously fixed inputs and outputs', Operations Research, Vol. 34, No. 4, pp.513-521.

Baykasoglu, A., Ozbay, E., Gogus, M.T. and Oztas, A. (2009) 'Contractor selection with multi criteria decision support tools', Int. J. Industrial and Systems Engineering, Vol. 4, No. 2, pp.174-197.

Beasley, J. (1990) 'Comparing university departments', Omega, Vol. 8, No. 2, pp.171-183.

Beasley, J. (1995) 'Determining teaching and research efficiencies', Journal of the Operational Research Society, Vol. 46, No. 4, pp.441-452.

Boscá, J.E., Liern, V., Martínez, A. and Sala, R. (2009) 'Increasing offensive or defensive efficiency? An analysis of Italian and Spanish football', Omega, Vol. 37, No. 1, pp.63-78.

Charnes, A., Cooper, W.W. and Rhodes, E. (1978) 'Measuring the efficiency of decision making units', European Journal of Operational Research, Vol. 2, No. 6, pp.429-444.

Cook, W.D., Green, R.H. and Zhu, J. (2006) 'Dual-role factors in data envelopment analysis', IIE Transactions, Vol. 38, No. 2, pp.105-115.

Cook, W.D. and Zhu, J. (2007) 'Classifying inputs and outputs in data envelopment analysis', European Journal of Operational Research, Vol. 180, No. 2, pp.692-699.

Cooper, W.W., Ruefli, T.W., Deng, H., Wu, J. and Zhang, Z. (2008) 'Are state-owned banks less efficient? A long- vs. short-run data envelopment analysis of Chinese banks', Int. J. Operational Research, Vol. 3, No. 59, pp.533-556. 
Cooper, W.W., Ruiz, J.L. and Sirvent, I. (2009) 'Selecting non-zero weights to evaluate effectiveness of basketball players with DEA', European Journal of Operational Research, Vol. 195, No. 2, pp.563-574.

El-Mashaleh, M., Rababeh, S.H. and Hyari, K.H. (2010) 'Utilizing data envelopment analysis to benchmark safety performance of construction contractors', Int. J. Project Management, Vol. 28, No. 1, pp.61-67.

Farzipoor Saen, R. (2010a) 'A new model for selecting third-party reverse logistics providers in the presence of multiple dual-role factors', Int. J. Advanced Manufacturing Technology, Vol. 46, Nos. 1-4, pp.405-410.

Farzipoor Saen, R. (2010b) 'Restricting weights in supplier selection decisions in the presence of dual-role factors', Applied Mathematical Modelling, Vol. 34, No. 10, pp.2820-2830.

Farzipoor Saen, R. (2010c) 'Technology selection in the presence of dual-role factors', Int. J. Advanced Operations Management, Vol. 2, Nos. 3/4, pp.249-262.

Farzipoor Saen, R. (2010d) 'A new model for ranking 3PL providers', Australian Journal of Basic and Applied Sciences, Vol. 4, No. 8, pp.3762-3769.

Farzipoor Saen, R. (in press) 'Media selection in the presence of flexible factors and imprecise data', Journal of the Operational Research Society.

Goncharuk, A.G. (2007) 'Using the DEA in efficiency management in industry', Int. J. Productivity and Quality Management, Vol. 2, No. 2, pp.241-262.

Kinnear, P.R. and Gray, C.D. (1994) SPSS for Windows Made Simple. East Sussex, UK: Lawrence Erlbaum Associates.

Liu, J., Ding, F.Y. and Lall, V. (2000) 'Using data envelopment analysis to compare suppliers for supplier selection and performance improvement', Supply Chain Management: An International Journal, Vol. 5, No. 3, pp.143-150.

Mahdiloo, M., Noorizadeh, A. and Farzipoor Saen, R. (2011) 'A new approach for considering a dual-role factor in supplier selection problem', Int. J. Academic Research, Vol. 3, No. 1, pp.254-259.

Mulwa, R., Emrouznejad, A. and Muhammad, L. (2009) 'Economic efficiency of smallholder maize producers in Western Kenya: a DEA meta-frontier analysis', Int. J. Operational Research, Vol. 4, No. 3, pp.250-267.

Noorizadeh, A., Mahdiloo, M. and Farzipoor Saen, R. (in press) 'Supplier selection in the presence of dual-role factors, nondiscretionary inputs, and weight restrictions', Int. J. Productivity and Quality Management.

Paradia, J.C., Rouatt, S. and Zhu, H. (2010) 'Two-stage evaluation of bank branch efficiency using data envelopment analysis', Omega, Vol. 39, No. 1, pp.99-109.

Parkan, C. (2006) 'An alternative derivation of the basic DEA models for gauging the productive performances of operating entities', Int. J. Productivity and Quality Management, Vol. 1, No. 3, pp.253-271.

Parkan, C. and Wang, J. (2007) 'Gauging the performance of a supply chain', Int. J. Productivity and Quality Management, Vol. 2, No. 2, pp.141-176.

Toloo, M. (2009) 'On classifying inputs and outputs in DEA: a revised model', European Journal of Operational Research, Vol. 198, No. 1, pp.358-360.

Tone, K. (2001) 'A slacks-based measure of efficiency in data envelopment analysis', European Journal of Operational Research, Vol. 130, No. 3, pp.498-509.

Tone, K. (2002) 'A slacks-based measure of super-efficiency in data envelopment analysis', European Journal of Operational Research, Vol. 143, No. 1, pp.32-41. 
Wong, W.P., Jaruphongsa, W. and Lee, L.H. (2008) 'Supply chain performance measurement system: a Monte Carlo DEA-based approach', Int. J. Industrial and Systems Engineering, Vol. 3, No. 2, pp.162-188.

Yang, F., Liang, L., Li, Z.H. and Du, S.H. (2010) 'Integrating dual-role variables in data envelopment analysis', Journal of Systems Engineering and Electronics, Vol. 21, No. 5, pp.771-776.

\section{Notes}

${ }^{1}$ To treat $w_{o}$ on both input and output sides in a same manner, dual-role factor is incorporated as a non-discretionary input on the input side.

${ }^{2}$ The presence of dual-role factor caused $1 / I$ and $\xi / R$ in Model (6) to be changed to $1 /(I+1)$ and $\xi_{2} /(R+1)$ in Models (7) and (8).

${ }^{3} \mathrm{SBM}$ model cannot be solved when there are zero values in the data set. However, the data used by Beasley $(1990,1995)$ and Cook et al. (2006) have some zero values in $x_{2}$ and $y_{2}$. In this case, we set $x_{2 o}$ and $y_{2 o}$ when they are zero to a small positive number $\varepsilon$ and continue the usual process. The value of $\varepsilon$ is proposed by Tone (2002) to be set, e.g. to: $\varepsilon=$ (the smallest positive $x_{2}$ and $y_{2}$ value in the data set) $/ 100$. 